Khazanah: Jurnal Studi Islam dan Humaniora

ISSN: 0215-837X (p); 2460-7606 (e), Vol. 17 (2), 2019, pp. 209-226

DOI: $10.18592 /$ khazanah.v17i2.3215

Submit : 15/08/2019 Review : 24/09/2019 Publish : 31/12/2019

\title{
ULAMA-DIFABEL: MENARASIKAN EKSPRESI KULTURAL MASYARAKAT BANJAR DALAM LENSA STUDI DISABILITAS
}

\author{
Barkatullah Amin \\ Universitas Islam Negeri Sunan Kalijaga, Yogyakarta. \\ barkatullah.amin93@gmail.com
}

\begin{abstract}
Ulama in Banjar society take place as religious elite whose roles are very important. They used to be treated specially in practice, like being honored and respected. However, what if there is Ulama who is physically and mentally different (difabel). Do people treat differently? How do people then perceive it? This paper aims to see how the attitudes and views of people in the Banjar community towards the "UlamaDifabel" - Islamic scholars with disabilities who participate in religious and community activities. This is a qualitative research with ethnography approach. It uses social model of disability theory. the results of this study explain that although the government has ratified the Law of the Republic of Indonesia No. 19 of 2011 concerning the Ratification of the CRPD, however, it cannot be called as the sole reason for the establishment of an inclusive paradigm that develops in society in a dominant way. In spite of that, the Banjar people interpret the existence of diffable scholars as a transcendent phenomenon because of the normative influence, metaphysical, and theological (Islam Banjar) views which both encourage each other to form social constructs with a paradigm of the Social Model of Disability in Banjar society. This phenomenon is also affected by some factors like people's understanding toward diffabled condition, culture, education, and religious doctrine accepted.
\end{abstract}

Keyword: Ulama-Difabel; Culture; Banjar Society; Disability Studies

\begin{abstract}
Abstrak: Ulama dalam masyarakat Banjar menempati posisi sebagai elit keagamaan yang perannya sangat penting. Sebingga pada praktiknya ulama sering mendapatkan perlakuan spesial, seperti dimuliakan dan dihormati. Namun, bagaimana jika ada ulama yang memiliki perbedaan pada fisik ataupun mentalnya (difabel), apakah perlakuan masyarakat menjadi berbeda? Bagaimana kemudian masyarakat mempersepsikannya? Paper ini bertujuan untuk melihat bagaimana sikap dan pandangan masyarakat Banjar terhadap Ulama-Difabel yang turut serta dalam kegiatan keagamaan maupun kemasyarakatan. Kajian ini bersifat kualitatif dengan pendekatan etnografi. Pisau analisisnya menggunakan teori Social Model of Disability. Hasil kajian ini menunjukkan bahwa meskipun pemerintah telah meratifikasi Undang-Undang Negara Republik. Indonesia Nomor 19 Tabun 2011 tentang Pengesahan CRPD, tetapi hal itu tidak bisa disebut sebagai satu-satunya alasan terbentuknya paradigma inklusif yang berkembang dalam masyarakat, yang kemudian mempengarubi cara pandang masyarakat secara dominan, tetapi lebih dari itu, masyarakat Banjar memaknai keberadaan Ulama-Difabel sebagai fenomena transenden, karena dipengarubi oleh pandangan-pandangan normatif, metafisike dan teologis (Islam Banjar) yang kemudian keduanya saling mendorong terbangunnya konstruksi sosial berparadigma Social Model of Disability pada masyarakat Banjar. Fenomena ini juga dipengarubi oleh faktor-faktor seperti; pemahaman masyarakat terhadap kondisi difabel itu sendiri, budaya, pendidikan, dan doktrin keagamaan yang diterima.
\end{abstract}

Kata kunci: Ulama-Difabel; Kultur; Masyarakat Banjar; Studi Disabilitas 


\section{Pendahuluan}

Sejak beberapa dekade yang lalu, disability studies telah menjadi diskursus menarik yang terus diperbincangkan di dunia akademik oleh para sarjana maupun peneliti yang fokus pada kajian minoritas terbesar dengan keberagaman jenis, pengalaman individu, komunitas, maupun kelembagaannya tersebut. ${ }^{1}$ Dalam kajian ini, telah banyak diskusi yang membahas tentang pelbagai hal, seperti; ragam teori/model disabilitas, dinamika, gerakan, kontestasi politik dan ideologi, hingga ragam perspektif yang mengikutinya. Berkaitan dengan hal tersebut, Ro'fah berargumen bahwa setiap fase peradaban telah melahirkan sebuah cara pandang yang beragam tentang fenomena disabilitas. Pada masa lampau, sebelum manusia mengenal ilmu pengetahuan modern, disabilitas kerap dimaknai dengan sesuatu yang jahat, dosa, atau sebaliknya, fenomena yang luar biasa. Setelah mengenal pengetahuan, maka muncul penjelasan yang lebih rasional tentang konsepsi disabilitas dari berbagai sudut pandang, baik medis, sosial, politik hingga agama. Pun demikian persepsi berkenaan tentang disabilitas tidak hanya membicarakan isu "the body" yang berorientasi kepada individu, tetapi juga lebih luas dari itu, yakni dari budaya ke budaya. $^{2}$

Hingga kini, diskusi tentang konstruksi disabilitas yang mengkristal dalam masyarakat masih dianggap sebagai kajian yang seksi untuk dikaji dan diangkat ke permukaan, apalagi yang berkenaan tentang kepercayaan atau bagaimana penyandang disabilitas dipersepsikan, baik dalam kacamata masyarakat, budaya maupun yang berhubungan dengan agama. Jika kemudian disabilitas dihubungkan dengan dimensi keagamaan, agama dalam berbagai manifestasinya, memainkan peran penting dalam menentukan bagaimana fenomena disabilitas dipahami dan bagaimana penyandang disabilitas diperlakukan secara historis dalam konteks budaya. ${ }^{3}$

Sejalan dengan paparan di atas, telah banyak penelitian yang membahas tentang agama dan disabilitas. Baik dalam tradisi Islam, Kristen dan agama-agama lainnya. Meskipun demikian, faktanya, riset yang ada tidak berimbang sama sekali. Dari sependek penelusuran penulis, riset-riset yang muncul (tentang agama dan disabilitas) masih berkutat pada wacana; sikap dan perlakuan masyarakat terhadap difabel, pengikutsertaan difabel dalam komunitas iman, perspektif lintas agama, perspektif dari pemuka-pemuka agama dan semacamnya. Akan tetapi kajian disability studies masih kekeringan dengan literatur yang membahas peran pemuka agama atau bagaimana masyarakat mempersepsikan pemuka agama yang memiliki disabilitas, atau yang penulis istilahkan dengan Ulama-Difabel.

Berkaitain dengan paparan di atas, penelitian tentang ulama Banjar misalnya, hanya terbatas pada kajian-kajian normatif dan antropologi atau kajian sosial lainnya yang secara spesifik belum ada yang terkait dengan studi disabilitas.

${ }^{1}$ Ishak Salim, "Perspektif Difabilitas Dalam Politik Indonesia" SIGAB: Jurnal Difabel 2, no. 2 (2015): 246.

${ }^{2}$ Ro'fah, “Teori Disabilitas: Sebuah Review Literatur” SIGAB: Jurnal Difabel 2, no. 2 (2015): 138.

${ }^{3}$ Darla Schumm and Michael Stoltzfus, Disability and Religious Diversity: Cross-Cultural and InterReligious Perspectives (United State: Palgrave Macmillan, 2011). 
Misalnya penelitian Ahdi Makmur yang berjudul "Peranan Ulama Dalam Membina Masyarakat Banjar di Kalimantan Selatan." Riset ini membahas tentang bagaimana ulama sebagai seseorang yang memiliki otoritas dalam urusan agama Islam sangat terkait dengan faktor pembentukan religiusitas masyarakat Banjar. Selain itu dalam tulisannya Makmur juga menjelaskan bahwa ualama menempati kedudukan yang strategis karena dipandang memiliki keilmuan agama yang tinggi, akhlak yang terpuji, kesalehan dan yang paling signifikan adalah karena mereka berperan dalam pembinaan religiusitas masyarakat Banjar. ${ }^{4}$

Selain itu peneliti yang membahas tentang riset keulamaan adalah Mirhan AM. Ia meneliti tentang "Karisma K.H. Muhammad Zaini Abdul Ghani Dan Peran Sosialnya (1942-2005)." Dalam riset tersebut Mirhan mengangkat tentang salah satu sosok ulama karismatik di Kalimantan Selatan, yaitu KH. Muhammad Zaini bin Abdul Ghani, atau yang dikenal dengan sebutan abah guru Sekumpul, dalam riset terebut Mirhan mengaitkan kekarismaan sosok guru Sekumpul tersebut dengan teori karismatiknya Weber dan selain itu Mirhan juga fokus pada peran sosialnya.

Hasil penelitian ini menunjukkan bahwa meskipun guru Sekumpul sudah wafat tetapi tidak dengan karismanya, Mirhan menemukan bahwa hingga saat ini makam guru Sekumpul tidak pernah sepi dari penziarah setiap harinya. Ia juga mengaitkan hal tersebut dengan makam Syekh Muhammad Arsyad al-Banjari atau yang dikenal dengan Datuk Kalampayan, atau makam Syekh Yusuf di Makassar atau makam Wali Songo di Jawa yang selalu didatangi para peziarah hampir setiap saat. Dari fenomena tersebut Mirhan berargumen bahwa sebuah karisma tidak akan hilang ketika seseorang meninggal dunia, ia juga sekaligus membantah teorinya Weber yang menyebutkan bahwa karisma akan sirna seiring dengan wafatnya sang tokoh. ${ }^{5}$

Riset selanjutnya yang berhubungan dengan keulamaan adalah "Ulama Banjar Kharismatik. Masa Kini di Kalimantan Selatan: Studi terbadap Figur Guru Bacbiet, Guru Danau, dan Guru Zubdi," yang ditulis oleh Mujiburrahman dkk, Riset ini sebenarnya secara implisit terhubung dengan riset Mirhan yang telah dibahas sebelumnya. Riset ini membahas tentang tiga figur ulama kharismatik masa kini yang ada di Kalimantan Selatan, yaitu K. H. Muhammad Bachieth (Guru Bachieth), K. H. Asmuni (Guru Danau) dan K. H. Ahmad Zuhdiannor (Guru Zuhdi). Ketiga ulama Banjar yang dibahas menunjukkan ciri-ciri seorang tokoh kharismatik berdasarkan teori kharisma dalam sosiologi. Mereka adalah tokoh-tokoh yang memiliki keistimewaan, dan tampil di saat krisis, baik krisis sosial yang tengah terjadi, ataupun krisis kepemimpinan ulama setelah wafatnya ulama kharismatik terkemuka di Kalimantan Selatan, Guru Zaini bin Abdul Ghani, yang dikenal dengan Guru Sekumpul. Hasil dari riset tersebut menjelaskan bahwa masing-masing tokoh memiliki pesona, yang mampu memukau ribuan khalayak yang setia mendengarkan ceramah-ceramahnya.

\footnotetext{
${ }^{4}$ Ahdi Makmur, "Peranan Ulama dalam Membina Masyarakat Banjar di Kalimantan Selatan," MIQOT Vol. XXXVI, no. 1 (June 2012): 174-91, http://dx.doi.org/10.30821/miqot.v36i1.114.

${ }^{5}$ Mirhan Mirhan, "Karisma KH Muhammad Zaini Abdul Ghani dan Peran Sosialnya (19422005)," Jurnal Ilmiah Ilmu Ushuluddin 12, no. 1 (2016): 142.
}

Khazanah, Vol. 17 (2), 2019 
Meskipun sama-sama memiliki kharisma, masing-masing tokoh memiliki keunikannya sendiri-sendiri. Di sisi lain, tiga tokoh ini tampaknya menunjukkan pergeseran pusat kharisma, dari Martapura di mana Guru Sekumpul menetap, menyebar ke tiga wilayah: Banjarmasin, Barabai, Tanjung. ${ }^{6}$

Berdasarkan dari sedikit penelusuran literatur review yang penulis lakukan, secara spesifik belum ada peneliti yang mengangkat penelitian tentang ulama dan disabilitas pada masyarakat Banjar. Sementara, pada beberapa kesempatan penulis sering melihat difabel yang menjadi ulama, yang berperan sebagai penceramah, pemimpin majelis ta'lim, ataupun ketua rombongan ziarah. Oleh karenanya, berangkat dari fenomena tersebut penulis tertarik untuk menelusuri lebih jauh dan mendiskusikannya pada paper ini, dengan menantang "tradisi" mainstream yang ada, dan mencoba memberikan pertanyaan-pertanyaan kritis dan mendasar tentang bagaimana respon masyarakat Banjar ketika seorang ulama yang menempati posisi penting dan vital dalam masyarakat hadir dengan kondisi fisik yang berbeda, atau apa yang penulis sebut dengan Ulama-Difabel. Bagaimana pandangan masyarakat tentang hal ini, kemudian, apakah perlakuan masyarakat menjadi berbeda, dan bagaimana kemudian masyarakat mempersepsikannya.

\section{Metode}

Berdasarkan fenomena di atas, paper ini akan mendiskusikan tentang bagaimana Ulama-Difabel dipersepsikan dan diperlakukan dalam masyarakat Banjar. Serta pada paper ini, penulis mencoba menguraikan makna Ulama-Difabel sebagai tawaran istilah baru pada wacana studi disabilitas dalam konteks keindonesiaan. Seperti penelitian-penelitian tentang budaya yang telah ada, ini adalah penelitian lapangan (field research) dengan jenisnya deskriptif-kualitatif dan pendekatannya adalah Etnografi. Dalam pemilihan subyek, penulis menggunakan teknik purposive sampling yang berarti proses pemilihan subyek penelitian dilakukan secara sengaja, sesuai dengan kategori dan karakteristik yang diinginkan. Kemudian untuk mengupasnya lebih dalam, penulis mengggunakan teori Social Model of Disability sebagai pisau analisisnya.

\section{Pembahasan \\ Ulama-Difabel dalam Perspektif Masyarakat Banjar Pengertian Ulama: Sebuah Penjelasan Singkat}

Sebelum Nabi Muhammad Saw wafat, Ia adalah pemegang otoritas tunggal urusan agama Islam. Ia bertugas untuk menyebarkan, mengajarkan dan mengawal ajaran Islam. Setelah wafat tugas dan tanggung jawab tersebut kemudian diteruskan oleh para sahabat, tabi'in dan hingga kemudian dilanjutkan oleh para ulama. Karena itu, ulama bertugas dan bertanggung jawab menyampaikan (pendakwah), mengajarkan (pendidik) dan memelihara ajaran Islam (pengawal). Ulama juga

${ }^{6}$ Mujiburrahman, M Zainal Abidin, and Rahmadi, "Ulama Banjar Kharismatik Masa Kini di Kalimantan Selatan: Studi Terhadap Figur Guru Bachiet, Guru Danau, Dan Guru Zuhdi,” AL$B A N J A R I$ 11, no. 2 (July 2012). 
disebutkan sebagai waratsat al-anbiyâ yaitu pewaris para Nabi. Seperti halnya warisan pada umumnya, ulama dimaksudkan dapat menjalankan peranan dan tugas yang telah dilakukan oleh Nabi sebagai penerusnya. Dengan demikian, tugas pokok ulama adalah berdakwah dan mendidik ummat sesuai ajaran Islam yang diwariskan oleh Nabi Muhammad. ${ }^{7}$

Jika didefinisikan secara bahasa, ulama menurut al-Isfahani dalam Nata adalah bentuk jamak dari kata 'alim (bahasa Arab), yang mengacu kepada seseorang yang memiliki ilmu atau pengetahuan agama di atas rata-rata kemampuan yang dimiliki orang lain, yang mana keilmuan tersebut dapat menjadikan seorang hamba takut dan tunduk kepada Allah.8 Secara lebih spesifik, Sayyid Quttub dalam Bakar dan Hanafi mengartikan ulama dengan merujuk kepada orang-orang yang senantiasa memikirkan dan memahami al-Qur'an. Demikian juga, ulama diberikan tugas dan tanggung jawab sebagai orang-orang yang harus menjaga dan mempertahankan hadis-hadis yang diwariskan oleh Rasulullah SAW. ${ }^{9}$ Rahardjo merumuskan beberapa indikator tentang seseorang yang bisa disebut ulama. Pertama, sebagai pengemban tradisi agama. Kedua, orang yang paham tentang hukum Islam. Ketiga, sebagai pelaksana hukum fiqih. ${ }^{10}$ Selain itu Hasan al-Bashri dalam kitab Tafsir Al-Maraghi Jilid VIII yang dikutip oleh Bakar dan Hanafi menyatakan bahwa yang dimaksud dengan ulama adalah orang yang takut kepada Allah, senang kepada sesuatu yang disenangi Allah, serta meninggalkan apa-apa yang dibenci oleh Allah. ${ }^{11}$

Dalam kalangan tokoh agama Islam, banyak interpretasi berkenaan dengan makna ulama itu sendiri, tetapi menurut Nata bagaimanapun bentuk perbedaan dalam masyarakat berkenaan tentang perspektif mereka tentang ulama, beberapa ahli dalam kajian Islam cenderung menganggap ulama adalah orang yang ahli dalam bidang al-Qur'an, sebagian yang lain menganggap ulama adalah orang yang fokus dan menjaga orisinalitas hadis, sebagian yang lain menganggap ulama adalah orang yang memiliki ilmu fikih yang tinggi. Tetapi menurut Nata, jika dipahami secara umum ulama dipandang sebagai orang yang memiliki ciri khas dengan pengetahuan dan wawasan yang luas tentang agama Islam, juga memiliki rasa khasyyah dalam rangka takut kepada Allah. ${ }^{12}$ Di Indonesia sendiri terdapat ragam penyebutan berkait dengan istilah ulama, misalnya teungku untuk daerah Aceh, di daerah sumatera dikenal dengan

${ }^{7}$ Makmur, "Peranan Ulama Dalam Membina Masyarakat Banjar Di Kalimantan Selatan," 174.

${ }^{8}$ Abuddin Nata, Pendidikan Dalam Perspektif Al-Qur'an, pertama Jakarta: Prenadamedia Group, 2016), 103.

${ }^{9}$ Muhammad Hasan Said Iderus, Latifah Abdul Majid, and Ahamad Asmadi Sakat, "Peranan

Ulama Banjar Abad Ke-20 Dalam Tradisi Penulisan Hadis Arba’̄n Di Banjar Dan Malaysia," AlBanjari Vol 15, no. 2 (December 2016): 146.

${ }^{10}$ Muhammad Dawam Rahardjo, Ensiklopedi Al-Qur" an (Jakarta: Paramadina, 1996), 684.

${ }^{11} \mathrm{Abu}$ Bakar and Imam Hanafi, "Berebut Paling Shaleh: Penguatan Identitas Ulama Di Era Milenial," Kontekstualita 32, no. 02 (2018): 76.

${ }^{12}$ Abuddin Nata, Pendidikan Dalam Perspektif Al-Qur'an, Pertama (Jakarta: Prenadamedia Group, 2016), 176.

Khazanah, Vol. 17 (2), 2019 
sebutan tuanku atau buya. ${ }^{13}$ Di pulau Jawa secara umum, ulama paling dikenal dan dekat dengan sebutan Kyai. Selain itu di Kalimantan Selatan ulama dikenal dengan sebutan guru, urang alim, tuan guru, abah guru, guru tuba, mu'allim dan sebagainya. ${ }^{14}$

\section{Mendefinisikan Ulama-Difabel}

Untuk memfilter luasnya pemahaman tentang apa yang penulis maksud dengan Ulama-Difabel, maka dari itu pada sub-bahasan ini penulis ingin mempertegas dan membatasi pemahaman berkait dengan makna istilah tersebut. Namun sebelum masuk kepada pembahasan tersebut penulis mencoba mendefinisikan kembali tentang apa yang dimaksud dengan difabel atau penyandang disabilitas.

Banyak sudah kontestasi yang hadir berkenaan dengan istilah difabel ataupun penyandang disabilitas. Dulu istilah yang sering dipakai adalah orang cacat, orang dengan ketunaan, dan lain sebagainya. "Setiap orang berpotensi menjadi penyandang disabilitas". Begitu narasi realistis yang sering penulis lihat pada beberapa paper yang mengangkat isu tentang disabilitas, karena menurut beberapa ahli dalam studi ini, seseorang dapat menjadi penyandang disabilitas bukan hanya pada masa kehamilan, tetapi juga pasca kehamilan, dari anak-anak, remaja hingga dewasa. Potensi ini disebabkan oleh banyak faktor, misalnya tragedi seperti kecelakaan, perkelahian atau bencana alam dan sebagainya. ${ }^{15}$

Jika mengacu kepada Undang-Undang Nomor 8 Tahun 2016 Tentang Penyandang Disabilitas maka yang dimaksud dengan penyandang disabilitas adalah "setiap orang yang mengalami keterbatasan fisik, intelektual, mental, dan/atau sensorik dalam jangka waktu lama yang dalam berinteraksi dengan lingkungan dapat mengalami hambatan dan kesulitan untuk berpartisipasi secara penub dan efektif dengan warga negara lainnya berdasarkan kesamaan bak". ${ }^{16}$

Difabel sendiri adalah kata eufemis ${ }^{17}$ yang dipilih oleh sekelompok temanteman aktivis gerakan yang fokus pada isu-isu disabilitas. Menurut Maftuhin (sejak artikelnya dibuat) kelompok yang paling banyak menggunakan istilah difabel adalah LSM-LSM di wilayah DIY dan Jateng, tetapi istilah tersebut sekarang ini sudah dikenal dan digunakan di berbagai daerah karena gencarnya advokasi maupun pemberitaan di media yang sudah banyak menggunakan istilah difabel (walaupun

${ }^{13}$ Muhammad Zainal Abidin, "Ulama in Indonesian Urban Society: A View of Their Role and Position in the Change of Age," Jurnal THEOLOGLA 28, no. 2 (February 20, 2018): 235-54, https://doi.org/10.21580/teo.2017.28.2.1863.

${ }^{14}$ Makmur, "Peranan Ulama dalam Membina Masyarakat Banjar di Kalimantan Selatan," 176.

15Jazim Hamidi, "Perlindungan Hukum Terhadap Disabilitas dalam Memenuhi Hak Mendapatkan Pendidikan dan Pekerjaan," Jurnal Hukum Ius Quia Iustum Vol. 23, no. 4 (October 2016): 653. Disabilitas," 2.

16"Undang-Undang Republik Indonesia Nomor 8 Tahun 2016 Tentang Penyandang

${ }^{17}$ Eufemis atau eufemisme adalah ungkapan yang lebih halus sebagai pengganti ungkapan yang dirasakan kasar, yang dianggap merugikan atau tidak menyenangkan, misalnya meninggal dunia untuk istilah mati. Lihat "Eufemisme," in KBBI Online, 18 November 2018, https://kbbi.web.id/eufemisme. 
masih inkonsisten). ${ }^{18}$ Istilah "difabel" sendiri berasal dari Bahasa Inggris "differently abled" atau disingkat diffabled. ${ }^{19}$ Menurut Maftuhin istilah yang muncul di Amerika Utara pada tahun 1990-an ini kemudian diadposi oleh para aktifis di Indonesia menjadi "difabel". ${ }^{20}$ Berdasarkan penjelasan tersebut secara singkat dapat disimpulkan bahwa istilah difabel dan penyandang disabilitas merujuk kepada makna yang sama.

Kemudian setelah memahami makna dari ulama dan difabel pada subbahasan sebelumnya, penulis mencoba mengikat makna dari Ulama-Difabel sebagai tawaran istilah baru dari penulis pada wacana studi disabilitas dalam konteks keindonesiaan dan kemudian memberikan batasan mengenai istilah tersebut dengan sependek pemahaman yang bisa penulis simpulkan.

Ulama-Difabel yang penulis maksudkan di sini adalah seorang ulama yang memiliki disabilitas (dengan ragam disabilitas yang ada) yang memiliki wawasan dan pemahaman yang baik perihal agama Islam, ditandai dengan peranannya sebagai guru agama, penceramah atau pemimpin majelis atau orang yang memiliki keahlian spritual lainnya, yang eksistensi dan keilmuan agamanya diakui oleh masyarakat sekitar dan turut berperan aktif dalam kegiatan keagamaan maupun kemasyarakatan.

\section{Kontestasi Teori Disabilitas}

Dalam diskursus disability studies, ada sejumlah teori atau model disabilitas yang biasanya digunakan untuk menganalisis isu-isu disabilitas. Setiap model memiliki pandangan yang khas dan pemaknaan berbeda terhadap disabilitas. Pertama Traditional Model of Disability atau apa yang disebut Ro'fah dengan istilah model moral. Model ini tidak dapat dipisahkan dengan historisitas disabilitas itu sendiri, model ini memandang disabilitas sebagai fenomena magis, diasosiasikan kepada pelanggaran pantangan, hukuman atau hadiah dari Tuhan dan hubungan kausalitas lainnya. ${ }^{21}$ Selain itu Maftuhin menggunakan istilah berbeda namun memiliki pemaknaan yang hampir sama, yaitu pendekatan kultural. Pendekatan ini berusaha memberikan pemahaman positif kepada individu difabel untuk menerima keadaannya, dan menyadari bahwa kondisi tersebut adalah bagian dari rencana Tuhan. Sebaliknya kepada non-difabel, pendekatan ini menurut Maftuhin menghendaki masyarakat untuk 'mengasihani' difabel dan menjadikan hidup mereka sebagai cerminan diri untuk bersyukur. ${ }^{22}$

Kedua, Individual/Medical Model of Disability. Model individu atau medis ini menurut Oliver dapat dijelaskan dengan dua hal. Pertama, model ini menempatkan problem disabilitas pada diri individu yang memiliki disabilitas dan kedua, model ini

${ }^{18}$ Arif Maftuhin, "Difabel Dan Penyandang Disabilitas," accessed November 17, 2018, http://pld.uin-suka.ac.id/2014/09/difabel-dan-penyandang-disabilitas.html.

${ }^{19}$ Urban Dictionary, "Diffabled," accessed November 17, 2018, https://www.urbandictionary.com/define.php?term=diffabled.

${ }^{20}$ Maftuhin, "Difabel Dan Penyandang Disabilitas." (2015): 138.

${ }^{21}$ Ro'fah, "Teori Disabilitas: Sebuah Review Literatur," SIGAB: Jurnal Difabel Vol 2, no. 2

${ }^{22}$ Arif Maftuhin, "Mendefinisikan Kota Inklusif: Asal-Usul, Teori dan Indikator," Tata Loka: Biro Penerbit Planologi Undip, 19, no. 2 (2017): 99.

Khazanah, Vol. 17 (2), 2019 
juga melihat penyebab masalah berasal dari keterbatasan fungsional atau kerugian psikologis yang diasumsikan timbul dari individu. Kedua poin ini didukung oleh apa yang disebut dengan 'the personal tragedy theory of disability' yang menunjukkan bahwa disabilitas adalah kejadian kebetulan, yang mengerikan, yang terjadi secara acak pada individu yang tidak beruntung. ${ }^{23}$

Dalam pandangan model ini normalisasi adalah tujuan utama, difabel dianggap perlu untuk diperbaiki dan dikembalikan "normal" seperti sedia kala. ${ }^{24}$ Sehingga model ini semata-mata hanya melahirkan kebijakan yang sifatnya rehabilitatif, karena difabel dikategorikan "sakit" atau "cacat", maka kebijakannya adalah 'menormalkan' atau 'menyembuhkan' si individu dari disabilitasnya. 25 Perspektif ini juga mengasumsikan bahwa fungsi intervensi atau pengobatan adalah untuk memulihkan disabilitas sehingga individu akan lebih mampu berfungsi dan bermanfaat dalam masyarakat. ${ }^{26}$ Menurut Maftuhin kebijakan-kebijakan pemerintah, melalui kementerian dan dinas sosial, masih banyak dipengaruhi oleh model ini. ${ }^{27}$ karena bentuk intervensi biasanya mencakup rehabilitasi medis dan penyediaan bantuan sosial. 28

Ketiga, Social Model of Disability. Model ini mencoba mengalihkan fokus masalah dari yang sifatnya individualistis kepada problem sosial. ${ }^{29}$ Dengan kata lain, persoalan disabilitas terletak pada faktor yang lebih luas dan bersifat eksternal yakni lingkungan sosial, dan bukan konsekuensi dari kekurangan fisik ataupun mental individu. ${ }^{30}$ Kaplan dalam Stone-MacDonald dan Butera berargumen bahwa Social Model menganggap disabilitas sebagai aspek normal kehidupan dan bukan dipandang sebagai penyimpangan, ia juga menolak anggapan tentang sifat "kecacatan" yang dilekatkan kepada para penyandang disabilitas. ${ }^{31}$

Secara singkat, ide besar Social Model adalah, bahwa jika lingkungan dirancang untuk keseluruhan fungsi manusia dan menggabungkan akomodasi dan dukungan yang sesuai, maka orang-orang dengan keterbatasan fungsional tidak akan mengalami "disabilitas" dalam artian mereka dapat sepenuhnya berpartisipasi dalam masyarakat. ${ }^{32}$ Walaupun pengaruh Social Model masih signifikan hingga saat ini, terutama pada

${ }^{23}$ Michael Oliver, Understanding Disability: From Theory to Practice (New York: S.t Martin's Press, 1996), 32.

${ }^{24}$ Kristjana Kristiansen, Simo Vehmas, and Tom Shakespeare, eds., Arguing about Disability: Philosophical Perspectives (London, New York, NY: Routledge, 2009), 2.

${ }^{25}$ Maftuhin, "Mendefinisikan Kota Inklusif: Asal-Usul, Teori Dan Indikator," 99.

${ }^{26}$ Angi Stone-MacDonald and Gretchen Digman Butera, "Cultural Beliefs and Attitudes about Disability in East Africa," Review of Disability Studies: An International Journal 8, no. 1 (2014): 3.

${ }^{27}$ Maftuhin, "Mendefinisikan Kota Inklusif: Asal-Usul, Teori Dan Indikator," 99.

${ }^{28}$ Daniel Mont, Measuring Disability Prevalence, SP Discussion Paper, No. 0706 (Washington, DC: World Bank, 2007), 2-3.

${ }^{29}$ Michael Oliver, Bob Sapey, and Pam Thomas, Social Work with Disabled People, 4th ed, Practical Social Work Series (New York: Palgrave Macmillan, 2012), 23.

${ }^{30}$ Ro'fah, “Teori Disabilitas: Sebuah Review Literatur," 2015, 147.

${ }^{31}$ Stone-MacDonald and Butera, "Cultural Beliefs and Attitudes about Disability in East Africa," 3.

${ }^{32}$ Mont, Measuring Disability Prevalence, 3. 
wilayah kebijakan dan politik, namun faktanya pendekatan ini bukan tanpa kritik. Kritikan terhadap pendekatan ini banyak dikemukakan terutama oleh para aktivis maupun akademisi difabel yang menganut mazhab post-stukturalis dan juga feminis, ${ }^{33}$ mereka menganggap bahwa Social Model mencoba menghilangkan subyektifitas individu difabel yang disebut sebagai "the pain of impairment", baik yang bersifat fisik maupun psikologis dengan menegasikan pengalaman yang dirasakan oleh para individu difabel. ${ }^{34}$

Walaupun demikian, Social Model telah memberikan kontribusi besar terhadap kehidupan difabel. karena menurut Ro'fah selain berkontestasi dengan Medical Model, Social Model juga turut andil dalam memberikan hak-hak bagi difabel, karena peran utamanya juga mempolitisasikan isu disabilitas yang memberi ruang bagi difabel untuk bicara dalam konteks atau wacana hak asasi dan kewarganegaraan (citizenship). Di sinilah terlihat jelas peran Social Model dalam memunculkan pendekatan hak (right based approach) yang kini bisa dikatakan sebagai hegemoni dominan dalam penyusunan kebijakan (policy making) dan program pelayanan disabilitas, baik dalam skala lokal maupun internasional, ${ }^{35}$ yang mana gagasannya telah merubah pandangan tentang disabilitas yang awalnya menganggap penyandang disabilitas sebagai obyek kebijakan menjadi subyek politik. Pandangan model ini berhubungan dengan temuan yang ada pada paper ini, yang mana masyarakat memberikan peluang dan ruang kepada difabel untuk menjadi apa yang mereka inginkan, salah satunya menjadi ulama. Hal ini sesuai dengan Undang-Undang nomor 8 tahun 2016 yang sudah mengatur hak-hak penyandang disabilitas sebagai bagian dari warga negara secara integral. ${ }^{36}$ Oleh karenanya penyandang disabilitas berhak menjadi apapun yang mereka inginkan, karena mereka memiliki hak yang dijamin oleh pemerintah berdasarkan landasan yuridis yang jelas.

\section{Gambaran Umum Disabilitas Pada Masyarakat Banjar}

Banjar dalam cakupan wilayah Kalimantan Selatan, adalah salah satu daerah yang kaya akan ragam adat, budaya, kesenian, dan khazanah lokal lainnya. Berkait dengan disabilitas, jika ditinjau menggunakan sudut pandang budaya dan kebahasaan, dalam lagu daerah Kalimantan Selatan, Ampar-Ampar Pisang 37, yang terkenal di seluruh

\footnotetext{
${ }^{33}$ Ro’fah, “Teori Disabilitas: Sebuah Review Literatur,” 2015, 152.

${ }^{34}$ Oliver, Understanding Disability: From Theory to Practice, 38.

${ }^{35}$ Ro'fah, “Teori Disabilitas: Sebuah Review Literatur,” 2015, 150.

${ }^{36}$ Lihat "Undang-Undang Republik Indonesia Nomor 8 Tahun 2016 Tentang Penyandang
} Disabilitas." menyebutkan bahwa Negara Kesatuan Republik Indonesia menjamin kelangsungan hidup setiap warga negara, termasuk para penyandang disabilitas yang mempunyai kedudukan hukum dan memiliki hak asasi manusia yang sama sebagai Warga Negara Indonesia dan sebagai bagian yang tidak terpisahkan dari warga negara dan masyarakat Indonesia merupakan amanah dan karunia Tuhan Yang Maha Esa, untuk hidup maju dan berkembang secara adil dan bermartabat.

${ }^{37} \mathrm{Pada}$ umumnya, isi dari lagu Ampar-Ampar Pisang menceritakan tentang pisang (yang dijadikan pisang rimpi) yang diampar (disusun) dan diburu oleh binatang kecil. Binatang ini dikenal masyarakat Kalimantan dengan nama bari-bari. Pada akhir lagu juga menceritakan tentang binatang yang ditakuti anak kecil zaman dulu (lihat kata "dikitip bidawang"). Konon, kata dikitip bidawang itu digunakan untuk menakuti anak anak yang suka mencuri pisang/kue rimpi yang masih dalam proses Khazanah, Vol. 17 (2), 2019 
daerah di Indonesia ini, ternyata memuat sebuah istilah lokal tentang penyebutan disabilitas pada bait-bait lagunya, yaitu kutung. lengkapnya, "siapa batis kutung dikitip bidawang". Dalam kamus Banjar-Indonesia sendiri, kutung sendiri diartikan sama dengan buntung. ${ }^{38}$ Senafas dengan makna diatas, kamus KKBI Online juga menyebutkan istilah kutung dengan arti buntung, selain itu definisikan dengan istilah terpotong. ${ }^{39}$ Dalam masyarakat Banjar sendiri, kata kutung digunakan untuk merujuk kepada seseorang yang tidak memiliki tangan ataupun kaki, biasanya sebagian masyarakat Banjar menyebutnya dengan sebutan kutung. Sebagian masyarakat juga sering memberikannya label ataupun gelar si kutung atau si utung. Atau menyebut nama orang seperti Anang kutung, Amat kutung dan lain sebagainya. ${ }^{40}$

Selain istilah kutung, masih banyak istilah-istilah lokal lain yang berkait dengan disabilitas, ini juga dikarenakan masyarakat Banjar kaya akan tradisi lisannya. Kemudian istilah yang paling umum dan paling sering digunakan dalam masyarakat Banjar adalah urang nang kurang, atau kada purna yaitu merujuk kepada kondisi seseorang yang memiliki kekurangan, atau diartikan sebagai "ketidaksempurnaan" baik secara fisik maupun secara mental. Kedua istilah ini adalah pandangan yang paling mendasar dari sebagian masyarakat untuk menjelaskan bagaimana difabel dianggap sebagai seseorang yang "kurang", "kekurangan" dan "tidak sempurna."

Beberapa masyarakat juga masih meyakini bahwa penyebab dari disabilitas yang dimiliki oleh difabel disebabkan oleh perlakuan buruk orang tua pada saat dan sebelum kehamilan, bagampiran, katulahan, atau akibat dari pamali. ${ }^{41}$ Oleh karenanya difabel di beberapa tempat dianggap sebagai aib oleh keluarga yang pada praktiknya pandangan-pandangan ini berdampak pada perlakuan dan sikap masyarakat terhadap difabel yang menganggap mereka adalah orang yang hina, atau dianggap sebagai makhluk yang lemah dan perlu dikasihani.

Tetapi walaupun dianggap merepresentasikan citra yang negatif terhadap difabel, namun perlu diberi catatan bahwa fenomena ini tidak tunggal, ada banyak temuan yang juga menunjukkan bahwa difabel dianggap orang yang istimewa, memiliki kelebihan dan dipandang sebagai sebuah fenomena yang positif, yang mana hal tersebut akan kita diskusikan pada bahasan dibawah ini.

penjemuran. Nusaidah Mufidah, “Ampar-Ampar Pisang," Perpustakaan Digital Budaya Indonesia, accessed November 18, 2018, https://budaya-indonesia.org/Ampar-ampar-Pisang. Selain itu lagu Ampar-Ampar Pisang juga dipraktikan dalam permainan tradisional yang mana pada praktiknya siapa yang akhirnya kakinya disentuh pada saat si pemimpin permainan menyebut kata "dikitip Bidawang" maka kakinya harus disembunyikan seakan-akan kakinya tersebut buntung.

38 Abdul Djebar Hapip, Kamus Banjar-Indonesia (Jakarta: Pusat Pembinaan Dan Pengembangan Bahasa, Departemen Pendidikan Dan Kebudayaan, 1977), 109.

39"Kutung" in Kamus Besar Bahasa Indonesia, accessed November 18, 2018, https://kbbi.web.id/kutung.

${ }^{40}$ Barkatullah Amin, "Konstruksi Disabilitas Pada Budaya Masyarakat Banjar" (Pascasarjana UIN Sunan Kalijaga, 2018), 89.

${ }^{41}$ Arni Daily, "Kekerabatan dan Interaksi Simbolik Bidan Kampung dengan Urang Halus dalam Masyarakat Banjar." Khazanah: Jurnal Studi Islam dan Humaniora 16, no. 2 (2018): 227-248. 


\section{Perspektif Masyarakat Banjar tentang Ulama-Difabel Sikap dan Perlakuan Masyarakat}

Dari kajian yang telah dilakukan, penulis mendapatkan beberapa temuan yang menarik berdasarkan sikap dan perlakuan masyarakat Banjar terhadap Ulama-Difabel. Pada umumnya kebanyakan dari masyarakat memandang difabel masih berbasis charity, namun seperti apa yang penulis sampaikan sebelumnya, fenomena ini tidak tunggal, ada keragaman perspektif yang sebenarnya juga patut untuk dieksplorasi lebih jauh berkait dengan nuansa positif yang dipahami oleh sebagian masyarakat Banjar tentang difabel. Khususnya sikap dan pandangan masyarakat tentang UlamaDifabel yang mendapatkan ruang dan bargaining position yang menarik dalam masyarakat Banjar yang berparadigma Social Model of Disability.

\section{Penghormatan Atas Ilmu Agama Yang Dimiliki}

Menurut observasi penulis dan menghadiri pengajian-pengajian agama, para penceramah sering mengutip ayat-ayat dalam al-Qur'an dan mengembangkannya kepada sebuah narasi-narasi yang mengajak jamaah pada ketakwaan, misalnya, "jangan pernah melihat seseorang dengan fisiknya, atau menghina seseorang karena fisiknya berbeda, atau tidak lebih baik dari kita, karena yang dilibat Allah bukan fisik ataupun pakaian kita, melainkan ketakwaan dan keimanan kita".

Narasi ini kemudian pada praktiknya memberikan angin segar kepada masyarakat yang secara penampilan maupun fisiknya memiliki perbedaan dengan orang-orang pada umumnya, termasuk para difabel yang narasi tersebut dapat menjadi bentuk legitimasi diri dalam masyarakat beragama. Dari narasi ini juga kita bisa melihat bagaimana relasi Islam atas kondisi difabel memiliki power sendiri dalam masyarakat Banjar, yang kemudian memberikan nilai-nilai positif terhadap difabel itu sendiri, juga masyarakat yang memandang mereka, ini juga berkaitan dengan pandangan masyarakat Banjar terhadap Ulama-Difabel, yang mana kemudian banyak masyarakat Banjar yang beranggapan bahwa bagaimanapun fisiknya seorang ulama, jikalau memiliki pemahaman dan wawasan agama Islam yang baik, maka harus dihormati. Sebagai penguat bahasan bisa dilihat pada hasil wawancara dengan salah satu informan dibawah ini:

"Bagaimanapun fisiknya, kalau orang tersebut mengkaji ilmu agama mesti dihormati orang, bukan hanya guru $A$, saya juga mengenal guru $B$, beliau buta, tapi beliau hapal qur'an, maulid babsyi juga hapal, maka harus dihormati, bagaimanapun fisiknya kalau dia orang 'alim maka barus dibormati". ${ }^{42}$

Dari hasil wawancara ini kita bisa melihat bagaimana tolok-ukur dinamika ini berangkat dari dimensi religiusitas masyarakat yang dipengaruhi oleh lingkungan dan budaya Islam yang masih kuat sebagai identitas Banjar.

\footnotetext{
${ }^{42}$ Informan 1, Pandangan Masyarakat Banjar terhadap Ulama-Difabel, March 12, 2018, 1.
}

Khazanah, Vol. 17 (2), 2019 


\section{Tidak Dibedakan Tetapi Dispesialkan}

Sebagian masyarakat juga memiliki pandangan yang unik tentang sikap mereka terhadap Ulama-Difabel, sebagian masyarakat berusaha tidak membedabedakan antara ulama yang difabel dengan ulama yang non-difabel, dan derajat mereka setara sebagai ulama orang yang memiliki status yang lebih tinggi dalam masyarakat daripada orang biasa pada umumnya, yang memiliki pemahaman agama yang biasa-biasa saja. Ini bisa dilihat dari salah satu hasil wawancara dengan informan dibawah ini:

"Tidak dibedakan tetapi dispesialkan, sama derajatnya, jadi sama dengan ulama yang biasa, tetapi dispesialkean karena kedisabilitasannya. Jikalau beliau melakukan kesalahan, jangan disalabkan tapi dispesialkan, jadi masyarakat yang mesti memakluminya misalnya tidak ada kaki, make angkat ke atas". ${ }^{43}$

Dari hasil wawancara di atas kita dapat memahami bagaimana pergeseran paradigma dari yang berbasis charity sesuai apa yang dipahami oleh model tradisional, kultural maupun medis, mencuat menjadi sebuah paradigma yang inklusif, yang mana konsep tentang disabilitas yang dipahami sebagai personal problem oleh model medis menjadi social problem, yang mana disabilitas menjadi tanggung jawab bersama. ${ }^{44}$

Menurut observasi dan dari beberapa data yang didapat melalui wawancara, penulis memahami bahwa ada dua pemaknaan tentang istilah spesial yang dipahami. Pertama, spesial yang dimaksud adalah perlakuan dan pemahaman yang lebih inklusif dari masyarakat terhadap kondisi yang dimiliki oleh Ulama-Difabel. Misalnya menggendong ulama ketika kesusahan dalam mengakses jalan yang ada, atau dalam arti masyarakat bisa memfasilitasi kebutuhan mereka. Kemudian makna spesial yang kedua adalah dimaksudkan untuk mengistimewakan seorang Ulama-Difabel karena ilmu agama yang dimilikinya (ini juga berkaitan dengan paparan sebelumnya). Banyak anggapan bahwa ketika seorang difabel tidak memiliki ilmu agama, maka sikap yang diberikan oleh masyarakat biasa-biasa saja, namun ketika ada difabel yang memiliki ilmu agama maka ia akan dianggap dan diperlakukan istimewa oleh masyarakat.

\section{Suci dan Bersih dari Perbuatan Dosa}

Disamping perihal yang dijelaskan sebelumnya, masyarakat Banjar juga masih memiliki pandangan yang magis perihal difabel, ini juga dipengaruhi oleh kejadiankejadian yang dianggap masyarakat Banjar sebagai sesuatu yang sakral. Misalnya di sebuah daerah di Kalimantan Selatan ada seseorang lelaki yang matanya buta dan menurut masyarakat sekitar lelaki tersebut mendapatkan Lailatul Qadr pada malam Nuzulul Qur'an. Kebanyakan dari mereka mempercayai ini karena masyarakat beranggapan seseorang yang buta tidak dapat melihat, tentu pandangannya suci dan terjaga dari hal-hal buruk, maksiat dan perbuatan dosa lainnya. Oleh karenanya banyak yang datang tidak hanya dari daerah tersebut, akan tetapi dari penjuru daerah lokal Kalimantan Selatan bahkan dari luar daerah pun datang untuk meminta doa dan

\footnotetext{
${ }^{43}$ Informan 2, Pandangan Masyarakat Banjar terhadap Ulama-Difabel, October 29, 2018.

${ }^{44}$ Oliver, Understanding Disability: From Theory to Practice, 34.
} 
meminta air dari seorang yang diyakini masyarakat mendapatkan Lailatul Qadr tersebut. Hasil wawancara lengkapnya bisa dilihat dibawah ini:

"Aku pernah mendengar, orangnya buta di daerah Tanjung, dia bukan ulama tapi seperti ulama, banyak orang yang meminta air kepadanya karena pada saat malam Nuzulul Qur'an beliau menerima anugerah sinar Lailatul Qadr, banyak orang yang datang meminta air, minta doa, minta sembubkan sakit panas, minta rezeki, dll. Menurutku beliau lebih dari ulama karena tidak semua ulama dapat lailatul qadar, kalau dia itu buta matanya tapi memang suci orangnya, kita yang khawas ini kalah dengan yang "picak." itu. ${ }^{5}$

\section{Sakti: Ulama-Difabel sebagai Konsultan Spritual}

Selain dianggap sebagai orang yang bersih dari dosa, sebagian masyarakat Banjar juga beranggapan Ulama-Difabel (disabilitas sensorik: Tunanetra) memilliki kesaktian. Salah satu informan menceritakan pengalamannya tentang seorang ulama yang buta (yang sudah meninggal puluhan tahun yang lalu) akan tetapi, meskipun dianggap memiliki kekurangan bagi sebagian orang, ulama tersebut diminati banyak orang karena kelebihan yang dimilikinya. Informan menceritakan bahwa ketika ulama tersebut masih hidup, beliau memiliki pandangan batin yang sangat tajam dan ilmu kebatinan yang kuat, atau yang dikenal dengan istilah kasyaf. Walaupun secara fisik Ia memiliki kebutaan pada matanya, akan tetapi para pengikutnya percaya bahwa ia adalah orang yang khawas secara batin. Sehingga banyak pengikutnya yang sepaham dengannya datang untuk meminta nasihat, meminta air, minta bantu melihat barang yang hilang dan segala macamnya. Sehingga banyak orang yang menganggap ulama tersebut sebagai konsultan spritual. Kemudian informan juga meyakini bahwa meskipun seseorang itu memiliki kekurangan akan tetapi ketika ia memiliki kelebihan maka posisinya istimewa dalam masyarakat. ${ }^{46}$

\section{Disabilitas Sebagai Bentuk Natural Dari Keragaman Manusia}

Selain hal-hal diatas, sebagian masyarakat juga beranggapan bahwa disabilitas dianggap sebagai sebuah bentuk natural dari keragaman manusia, jadi ketika ada ulama yang memiliki fisik ataupun kondisi lainnya yang berbeda dari umumnya, maka hal tersebut dianggap sebagai bagian dari bentuk keragaman manusia. Statemen ini bisa kita lihat dari salah satu hasil wawancara dibawah ini:

"Secara umum di martapura masib banyak aja guru-guru di Pondok atau ulama yang cadel, lidabnya kaku dan apapun itu, tidak mengecualikan mereka, artinya bal tersebut masuk dalam keragaman manusia, sifatnya natural". 47

Menarik untuk diperhatikan bahwa seorang informan menyatakan disabilitas adalah bentuk natural dari keragaman manusia, dan dapat dipahami bahwa informan mencoba mengaitkan disabilitas dengan problem-problem umum yang sering dimiliki oleh manusia pada umumya, seperti cadel, ataupun lidah kaku. Sejalan dengan ini, Anastasiou dkk berpendapat bahwa disabilitas merupakan bagian khusus dari

\footnotetext{
${ }^{45}$ Informan 3, Pandangan Masyarakat Banjar terhadap Ulama-Difabel, March 21, 2018.

${ }^{46}$ Informan 4, Pandangan Masyarakat Banjar terhadap Ulama-Difabel, March 29, 2018.

${ }^{47}$ Informan 5, Pandangan Masyarakat Banjar terhadap Ulama-Difabel, October 29, 2019.

Khazanah, Vol. 17 (2), 2019
} 
keragaman manusia yang tidak cukup dipahami oleh konsep keragaman budaya dalam akal sehatnya. Menurut Anastasiou dkk dalam beberapa kasus, kemajuan dalam sains dan teknologi telah mengubah ketidakmampuan menjadi sebuah ukuran normalitas. ${ }^{48}$ Ketika orang tidak mampu menggunakan teknologi dan apapun yang berkaitan dengan sesuatu yang menitikberatkan pada kemampuan individu maka orang dianggap tidak normal. Padahal keragaman manusia adalah gagasan yang lebih luas daripada keragaman budaya, karena jika ketika berbicara tentang manusia, maka pembahasannya akan komplek sekali, karena karakter manusia dengan manusia yang lain saja sudah berbeda. Inilah mengapa disabilitas tidak hanya dipandang dengan kacamata keragaman budaya tetapi juga sebagai bentuk keragaman manusia.

\section{Analisis Peran dan Posisi Ulama-Difabel dalam Masyarakat Banjar}

Berkaitan dengan peran dan posisi dalam masyarakat, ulama dalam masyarakat Banjar memiliki kedudukan yang sangat strategis baik dalam urusan pemerintahan, kemasyarakatan ataupun keagamaan. Masyarakat Banjar berkenaan dengan hal ini menititikberatkan ulama pada keahlian agama yang dimiliki, oleh karena itu banyak masyarakat yang mengesampingkan perihal fisik pada diskusi mereka tentang ulama, tentunya dengan beberapa alasan.

Pertama, karena mayoritas masyarakat Banjar beragama Islam maka sebagian masyarakat, orientasi berpikirnya seringkali menyentuh pada tataran normatif, karena menurut Daud, Islam sudah menjadi khas dan corak Banjar sejak dulu dengan pengaruh raja-raja Banjar yang menganut Islam ${ }^{49}$, yang kemudian pada praktiknya Islam telah menjadi basis hukum kerajaan Banjar, yang mana Islam tidak hanya dipahami sebagai landasan normatif, melainkan juga sebagai identitas sosio-kultural masyarakat Banjar. ${ }^{50}$ Sehingga mempengaruhi cara pandang masyarakat Banjar tentang ulama. Kedua, sebagian masyarakat Banjar juga memiliki rasa segan dan takut katulahan (terkena tulah), terutama bagi masyarakat yang memiliki pandangan traditional model, yang pandangannya masih berorientasi pada norma-norma baikburuk, yang kemudian beranggapan bahwa ulama sebagai wali Allah, atau orang yang memiliki kelebihan dari Allah, oleh karenanya masyarakat Banjar tidak terlalu berani berkomentar perihal kondisi fisik para ulama.

Ketiga, Selain itu, doktrin agama dan pengaruh agen juga memiliki pengaruh yang sangat besar dalam pembentukan konstruksi yang ada pada masyarakat. Agenagen ini termasuk penceramah maupun ulama yang sering memberikan penjelasan tentang betapa pentingnya sebuah ketakwaan daripada bentuk dan tampilan fisik, sehingga secara signifikan tidak ada perbedaan perlakuan antara Ulama-Difabel dengan ulama non-difabel.

${ }^{48}$ Dimitris Anastasiou, James M. Kauffman, and Domna Michail, "Disability in Multicultural Theory: Conceptual and Social Justice Issues," Journal of Disability Policy Studies 27, no. 1 (June 2016): 3, https://doi.org/10.1177/1044207314558595.

${ }^{49}$ Alfani Daud, Islam Dan Masyarakat Banjar (Jakarta: PT Raja Grafindo Persada, 1997), 5.

${ }^{50}$ Sumasno Hadi, "Studi Etika Tentang Ajaran-Ajaran Moral Masyarakat Banjar,"," Tashwir, 3, no. 6 (June 2015): 214. 
Berdasarkan penjelasan di atas, terdapat kesesuaian dengan apa yang penulis dapatkan pada observasi dan proses wawancara, bahwa masyarakat memperlakukan dan memposisikan Ulama-Difabel sama seperti ulama pada umumnya. Mereka beranggapan siapapun boleh menjadi ulama, asal dengan catatan memiliki keilmuan yang mumpuni tentang agama Islam. Masyarakat beranggapan bahwa perbedaan fisik tidak menjadikan seseorang dikecualikan dalam masyarakat, selama ulama tersebut memiliki wawasan dan kompetensi yang mumpuni dalam perihal agama maka harus didukung dan dihormati. Perihal perbedaan, yang paling umum adalah perbedaan yang hanya mengacu kepada keahlian masing-masing yang dimiliki, atau keilmuan agama yang lebih dikuasai

Sebagian besar masyarakat berargumen bahwa difabel adalah seseorang yang tidak terpisahkan dengan hak-haknya sebagai bagian warga negara, oleh karena itu mereka juga memiliki kesempatan untuk menjadi ulama. ${ }^{51}$ Pandangan masyarakat Banjar seperti ini berkesesuaian dengan paham Social Model yang memunculkan rights based approach yaitu pendekatan yang mencoba memberi ruang bagi difabel untuk muncul dipermukaan masyarakat mainstream sebagai bagian penuh dari masyarakat yang utuh haknya. ${ }^{52}$ Pandangan ini dikuatkan dengan adanya Konvensi tentang HakHak Penyandang Disabilitas (The Convention on the Rights of Persons with Disabilities) atau yang disingkat CRPD, yang diadopsi pada 2006 dan mulai berlaku pada tahun 2008, menandai "perubahan paradigma" dari pendekatan yang basisnya medis dan tradisional yang berorientasi pada individu penyandang disabilitas menjadi isu yang berbasis pada hak asasi manusia. Itu membuat jelas bahwa difabel berhak hidup mandiri di masyarakat, untuk membuat pilihan mereka sendiri dan untuk memainkan peran aktif dalam masyarakat..$^{53}$ Kemudian pada tahun 2011 kebijakan ini diratifikasi di Indonesia yang tertuang dalam Undang-Undang Negara Republik Indonesia Nomor 19 Tahun 2011 tentang Pengesahan CRPD yang bertujuan untuk memajukan, melindungi, dan menjamin kesamaan hak dan kebebasan yang mendasar bagi semua penyandang disabilitas, serta penghormatan terhadap martabat penyandang disabilitas sebagai bagian yang tidak terpisahkan dari masyararakat secara integral. ${ }^{54}$ Termasuk menjadi ulama bagi difabel walaupun penjelasannya tidak tertuang pada Undang-Undang secara langsung.

Meskipun pemerintah telah meratifikasi konvensi tersebut, tetapi hal tersebut tidak bisa disebut sebagai atau menjadi satu-satunya alasan terbentuknya paradigma inklusif yang berkembang dalam masyarakat, yang kemudian mempengaruhi pandangan masyarakat secara dominan, tetapi lebih dari itu, masyarakat Banjar

51 Pandangan Masyarakat Banjar terhadap Ulama-Difabel, Informan 1, March 12, 2018; Informan 2, October 29, 2018; Informan 3, March 21, 2018; Informan 4, March 29, 2018, 4; Informan 5, October 29, 2019.

${ }^{52}$ Ro'fah, “Teori Disabilitas: Sebuah Review Literatur,” 2015, 150.

${ }^{53}$ United Nations Human Rights Office the High Commisioner, "Human Rights of Persons with Disabilities,” accessed November 20, 2018, https://www.ohchr.org/en/issues/disability.

${ }^{54}$ Rahayu Repindowaty Harahap and Bustanuddin, "Perlindungan Hukum terhadap Penyandang Disabilitas menurut Convention on the Rights of Persons with Disabilities (CRPD)," Jurnal Inovatif VIII, no. 1 (January 2015): 19, https://online-journal.unja.ac.id/jimih/article/view/2191. Khazanah, Vol. 17 (2), 2019 
memaknai fenomena tersebut sebagai fenomena transenden, karena dipengaruhi oleh pandangan-pandangan normatif, metafisik dan teologis (Islam Banjar) yang akhirnya keduanya saling mendorong terbangunnya konstruksi sosial berparadigma Social Model of Disability pada sebagian masyarakat Banjar saat ini.

\section{Simpulan}

Argumen-argumen yang muncul pada penelitian ini telah berusaha menggambarkan tentang bagaimana Ulama-Difabel dipersepsikan dalam masyarakat Banjar. Pada umumnya persepsi masyarakat tentang Ulama-Difabel terlihat berparadigma inklusif, yakni berbasis kepada hak-hak individu sebagai bagian dari masyarakat, tentu dengan mempertimbangkan kompetensi keilmuan dan wawasan keislaman yang dimiliki. Tetapi jika membicarakan disabilitas secara umum, maka sikap dan perlakuan masyarakat tidak semua sama, tergantung kepada subyek yang ditanyakan, tidak dapat digeneralisasi, karena fenomenanya tidak tunggal, ada keragaman perspektif berkenaan dengan sikap dan perlakuan masyarakat Banjar secara umum.

Tetapi, ketika kita mendiskusikan difabel yang berperan sebagai ulama tentu akan berbeda dengan difabel yang tidak memiliki pencapaian apa-apa, tetapi jika kita mencoba mendiskusikan perbedaan ulama yang difabel dengan ulama yang nondifabel maka responnya tidak terlalu berbeda bahkan terkesan sama. Distingsi ini menjadi menarik karena pencapaian individu seorang difabel ternyata memiliki pengaruh besar dalam kehidupan mereka, sehingga tidak hanya ulama difabel yang dihormati, namun begitu pula perlakuan terhadap difabel lainnya yang dihargai eksistensinya di masyarakat karena mampu menunjukkan pencapaian di luar hambatan yang mereka miliki. Berkenaan dengan temuan ini penulis menyadari bahwa argumen-argumen tersebut sebagian besar sudah mengacu kepada teori Social Model yang berusaha memberikan ruang kepada difabel untuk mendapatkan hak penuh sebagai warga negara secara integral. Namun, walaupun paradigma ini tumbuh dan mulai berkembang dalam masyarakat, akan tetapi hal tersebut juga tidak bisa dipisahkan dari pengaruh nilai-nilai budaya dan agama Islam yang disebut telah menjadi identitas budaya dalam masyarakat Banjar.

\section{Daftar Pustaka}

Abidin, Muhammad Zainal. "Ulama in Indonesian Urban Society: A View of Their Role and Position in the Change of Age." Jurnal THEOLOGLA 28, no. 2 (February 20, 2018): 235-54. https://doi.org/10.21580/teo.2017.28.2.1863.

Amin, Barkatullah. "Konstruksi Disabilitas Pada Budaya Masyarakat Banjar." Pascasarjana UIN Sunan Kalijaga, 2018.

Anastasiou, Dimitris, James M. Kauffman, and Domna Michail. "Disability in Multicultural Theory: Conceptual and Social Justice Issues." Journal of Disability Policy Studies 27, no. 1 (June 2016): 3-12. https://doi.org/10.1177/1044207314558595. 
Bakar, Abu, and Imam Hanafi. "Berebut Paling Shaleh: Penguatan Identitas Ulama Di Era Milenial.” Kontekstualita 32, no. 02 (2018).

Daily, Arni. "Kekerabatan dan Interaksi Simbolik Bidan Kampung dengan Urang Halus dalam Masyarakat Banjar." Khazanah: Jurnal Studi Islam dan Humaniora 16, no. 2 (2018).

Daud, Alfani. Islam Dan Masyarakat Banjar. Jakarta: PT Raja Grafindo Persada, 1997.

"Eufemisme." In KBBI Online. Vol. 17 November 2018, n.d. https://kbbi.web.id/eufemisme.

Hadi, Sumasno. "Studi Etika Tentang Ajaran-Ajaran Moral Masyarakat Banjar,"," Tashwir Vol. 3, no. 6 (June 2015).

Hamidi, Jazim. "Perlindungan Hukum Terhadap Disabilitas Dalam Memenuhi Hak Mendapatkan Pendidikan Dan Pekerjaan.” Jurnal Hukum Ius Quia Iustum Vol. 23, no. 4 (October 2016).

Hapip, Abdul Djebar. Kamus Banjar-Indonesia. Jakarta: Pusat Pembinaan Dan Pengembangan Bahasa, Departemen Pendidikan Dan Kebudayaan, 1977.

Harahap, Rahayu Repindowaty, and Bustanuddin. "Perlindungan Hukum Terhadap Penyandang Disabilitas Menurut Convention On The Rights Of Persons With Disabilities (CRPD)." Jurnal Inovatif Vol. VIII, no. 1 (January 2015). https://online-journal.unja.ac.id/jimih/article/view/2191.

Iderus, Muhammad Hasan Said, Latifah Abdul Majid, and Ahamad Asmadi Sakat. "Peranan Ulama Banjar Abad Ke-20 Dalam Tradisi Penulisan Hadis Arba'īn Di Banjar Dan Malaysia." Al-Banjari Vol 15, no. 2 (December 2016): 127232.

Kristiansen, Kristjana, Simo Vehmas, and Tom Shakespeare, eds. Arguing about Disability: Philosophical Perspectives. London ; New York, NY: Routledge, 2009.

"Kutung." In Kamus Besar Bahasa Indonesia, November 18, 2018. https://kbbi.web.id/kutung.

Maftuhin, Arif. "Difabel Dan Penyandang Disabilitas." Accessed November 17, $2018 . \quad$ http://pld.uin-suka.ac.id/2014/09/difabel-dan-penyandangdisabilitas.html.

. "Mendefinisikan Kota Inklusif: Asal-Usul, Teori Dan Indikator." Tata Loka: Biro Penerbit Planologi Undip Vol. 19, no. 2 (2017).

Makmur, Ahdi. "Peranan Ulama Dalam Membina Masyarakat Banjar Di Kalimantan Selatan." MIQOT Vol. XXXVI, no. 1 (June 2012): 174-91. http://dx.doi.org/10.30821/miqot.v36i1.114.

Mirhan, Mirhan. "Karisma KH Muhammad Zaini Abdul Ghani dan Peran Sosialnya (1942-2005)." Jurnal Ilmiah Ilmu Ushuluddin 12, no. 1 (2016): 59-86. 
Mont, Daniel. Measuring Disability Prevalence. SP Discussion Paper, No. 0706. Washington, DC: World Bank, 2007.

Mufidah, Nusaidah. "Ampar-Ampar Pisang." Perpustakaan Digital Budaya Indonesia. Accessed November 18, 2018. https://budaya-indonesia.org/Ampar-amparPisang.

Mujiburrahman, M Zainal Abidin, and Rahmadi. "Ulama Banjar Kharismatik Masa Kini di Kalimantan Selatan: Studi Terhadap Figur Guru Bachiet, Guru Danau, Dan Guru Zuhdi." AL-BANJARI 11, no. 2 (July 2012).

Nata, Abuddin. Pendidikan Dalam Perspektif Al-Qur'an. Pertama. Jakarta: Prenadamedia Group, 2016.

—. Pendidikan Dalam Perspektif Al-Qur'an. Pertama. Jakarta: Prenadamedia Group, 2016.

Oliver, Michael. Understanding Disability: From Theory to Practice. New York: S.t Martin's Press, 1996.

Oliver, Michael, Bob Sapey, and Pam Thomas. Social Work with Disabled People. 4th ed. Practical Social Work Series. New York: Palgrave Macmillan, 2012.

rahardjo, Muhammad Dawam. Ensiklopedi Al-Qur" an. Jakarta: Paramadina, 1996.

Ro'fah. “Teori Disabilitas: Sebuah Review Literatur” 2, no. 2 (2015): 137-60.

. "Teori Disabilitas: Sebuah Review Literatur." SIGAB: Jurnal Difabel Vol 2, no. 2 (2015): 137-60.

Salim, Ishak. "Perspektif Difabilitas Dalam Politik Indonesia" 2, no. 2 (2015): 227 58.

Schumm, Darla, and Michael Stoltzfus. Disability and Religious Diversity: Cross-Cultural and Inter-Religious Perspectives. United State: Palgrave Macmillan, 2011.

Stone-MacDonald, Angi, and Gretchen Digman Butera. "Cultural Beliefs and Attitudes about Disability in East Africa." Review of Disability Studies: An International Journal Vol. 8, no. 1 (2014).

"Undang-Undang Republik Indonesia Nomor 8 Tahun 2016 Tentang Penyandang Disabilitas," n.d.

United Nations Human Rights Office the High Commisioner. "Human Rights of Persons with Disabilities." Accessed November 20, 2018. https://www.ohchr.org/en/issues/disability/pages/disabilityindex.aspx.

Urban Dictionary. "Diffabled." Accessed November 17, 2018. https://www.urbandictionary.com/define.php?term=diffabled. 